\title{
Investigating the mechanism of aortic valve stenosis: the role of magnesium salts
}

\author{
V Dritsa ${ }^{1}$, K Pissaridi ${ }^{1}$, J Anastassopoulou' ${ }^{1}$ E Koutoulakis ${ }^{2}$, I Mamarelis ${ }^{3}$, Chr Kotoulas ${ }^{4 *}$ \\ From 23rd World Congress of the World Society of Cardio-Thoracic Surgeons \\ Split, Croatia. 12-15 September 2013
}

\section{Background}

The calcification ofaortic valves is a common diseaseand valve replacement is the only established treatment. Herewith, we use infrared (FT-IR) spectroscopyto investigate and characterize the mineral deposits in order to understand the mechanism of aortic valve calcification and stenosis.

\section{Methods}

30 aortic valves of patients (65-80 years), who underwent surgical aortic valve replacement due to aortic stenosis, were used. The ATR-FT-IR spectra were recorded with a Nicolet 6700 thermoscientific spectrometer. SEM-EDX and XRD were from Fei Co, the Netherlands and Simens D-500 X-Ray diffractometer, respectively.

\section{Results}

The changes of FT-IR spectraat $1743 \mathrm{~cm}^{-1}$ resulted from hyperoxidation of lipids due to oxidative stress. The characteristic bands at the spectral regions $1200-900 \mathrm{~cm}^{-1}$ and $700-400 \mathrm{~cm}^{-1}$ showed the formation of low crystallinity biological hydroxyapatite $\left(\mathrm{Ca}_{10}\left(\mathrm{PO}_{4}\right)_{6}(\mathrm{OH})_{2}\right)$ and calcium monophosphate $\left(\mathrm{CaHPO}_{4}\right)$ salts. The results were confirmed using SEM-EDAX and XRD analysis. The observed cross-linking bonds between collagen and elastin were the principal sites for calcium deposition and progression. The findings confirmed the hypothesis that hydroxyapatite is formed predominantly due to ATP cycle, where the release of phosphate anions take place in ischemic pathways.

\section{Conclusions}

The characteristic FT-IR absorption bands of calcified aortic valves showed hyperoxidation of membranes

\footnotetext{
* Correspondence: chrkotoulas@gmail.com

${ }^{4}$ Department of Cardiac Surgery, «laso» General Hospital of Athens, Greece

Full list of author information is available at the end of the article
}

(a pro-inflammation stage), while the mineral deposits were consistent of low crystallinity biological hydroxyapatite, $\mathrm{Ca}_{2} \mathrm{HPO}_{4}$ and calcium phosphates. SEM-EDAX data showed substitution of calcium cations from magnesium cations leading to amorphous salts, preventing thus the aortic valve stenosis. Treatment of these patients with magnesium salts maybe could reduce the progress of aortic valve stenosis after valve replacement.

\section{Authors' details}

${ }^{1}$ Chemical Engineering Department, Radiation Chemistry \& Biospectroscopy, National Technical University of Athens, Greece. ${ }^{2}$ Department of Cardiology, NIMTS Veteran Hospital of Athens, Greece. ${ }^{3}$ Department of Cardiology, 401 Army General Hospital of Athens, Greece. ${ }^{4}$ Department of Cardiac Surgery, «laso» General Hospital of Athens, Greece.

Published: 11 September 2013

doi:10.1186/1749-8090-8-S1-018

Cite this article as: Dritsa et al:: Investigating the mechanism of aortic valve stenosis: the role of magnesium salts. Journal of Cardiothoracic Surgery 2013 8(Suppl 1):018.

Submit your next manuscript to BioMed Central and take full advantage of:

- Convenient online submission

- Thorough peer review

- No space constraints or color figure charges

- Immediate publication on acceptance

- Inclusion in PubMed, CAS, Scopus and Google Scholar

- Research which is freely available for redistribution

Submit your manuscript at www.biomedcentral.com/submit

\section{() Biomed Central}

C Biomed Central

C 2013 Dritsa et al; licensee BioMed Central Ltd. This is an Open Access article distributed under the terms of the Creative Commons Attribution License (http://creativecommons.org/licenses/by/2.0), which permits unrestricted use, distribution, and reproduction in any medium, provided the original work is properly cited. 